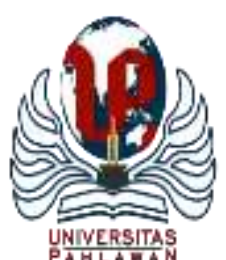

\title{
JURNALBASICEDU
}

Volume 6 Nomor 1 Tahun 2022 Halaman 664 - 674

Research \& Learningin Elementary Education

https://jbasic.org/index.php/basicedu

\section{Analisis Kemampuan Pemecahan Masalah Matematika Siswa dalam Menyelesaikan Sistem Persamaan Linear Tiga Variabel}

\author{
Patima M. Usman ${ }^{1}$, Isal Tintis ${ }^{2}$, Elok Faik Khotun Nihayah ${ }^{3 凶}$ \\ Program Studi Pendidikan Matematika, Universitas Tompotika Luwuk Banggai, Indonesia ${ }^{1,2,3}$ \\ E-mail: fatimausman366@ gmail.com ${ }^{1}$, isaltintis69@ gmail.com ${ }^{2}$, elokmath72@ gmail.com $^{3}$
}

\begin{abstract}
Abstrak
Dalam proses pembelajaran, sebagian besar siswa di kelas X MA Alkhairaat Pagimana belum memahami langkah-langkah penyelesaian masalah matematika khususnya pada materi Sistem Persamaan Linear Tiga Variabel (SPLTV). Olehnya itu, penelitian ini bertujuan untuk mendeskripsikan kemampuan pemecahan masalah matematika siswa dalam menyelesaikan soal SPLTV dan juga faktor-faktor yang mempengaruhinya. Penelitian ini termasuk ke dalam jenis penelitian deskriptif eksploratif dengan pendekatan kualitatif. Instrumen yang digunakan adalah tes kemampuan pemecahan masalah matematika dan pedoman wawancara. Pengecekan keabsahan data dilakukan dengan triangulasi teknik yakni memeriksa data dari beberapa subjek dengan menggunakan teknik yang berbeda. Adapun indikator kemampuan pemecahan masalah matematika dalam penelitian ini yaitu: 1) mengidentifikasi masalah, 2) merencanakan penyelesaian masalah, 3) melaksanakan rencana penyelesaian, dan 4) mengevaluasi masalah. Hasil penelitian ini menunjukkan bahwa siswa berkemampuan tinggi memiliki kemampuan pemecahan masalah matematika dalam kategori "baik". Namun, ada satu indikator yang tidak dipenuhi yaitu mengevaluasi masalah. Hal tersebut disebabkan oleh faktor kebiasaan siswa dalam menjawab dengan tidak mengevaluasi masalah terlebih dahulu. Sedangkan siswa berkemampuan rendah memiliki kemampuan pemecahan masalah matematika dalam kategori "kurang". Faktor penyebabnya adalah, kurangnya kemampuan dasar matematika, kurang aktif dalam proses pembelajaran, kurang memperhatikan guru ketika menjelaskan, dan pengaruh pergaulan siswa di sekolah.
\end{abstract}

Kata Kunci: Kemampuan Pemecahan Masalah Matematika, SPLTV.

\begin{abstract}
The learning process, most students in class X MA Alkhairaat Pagimana have not understood the steps of solving mathematical problem, especially in the three Linear Equation System (SPLTV). Therefore, this study aims to describe students' math problem solving skills in SPLTV as well as the factors that affect them. This research belongs to an exploratory descriptive research with qualitative approach. The instruments used are tests of mathematical problem solving skills and interview guidelines. Checking the validity of data is done by triangulation technique that checks data from several subjects using different techniques. Indicators of mathematical problem solving ability in this study are: 1) identifying problems, 2) planning problem solving, 3) implementing a solving plan, and 4) evaluating problems. The results of this study showed that highly capable students had the ability to solve math problems in the "good" category. However, there is one indicator that is not met which is evaluating problem. This is due to factor habits of students in answering by not evaluating problem. While low skilled students have ability to solve mathematical problems in the category "less". The contributing factors are, lack of basic mathematical skills, less active in the learning process, less attention to teachers when explaining, and the influence of student association in school.
\end{abstract}

Keywords: Math Problem Solving Skills, SPLTV.

Copyright (c) 2022 Patima M. Usman, Isal Tintis, Elok Faik Khotun Nihayah

$\triangle$ Corresponding author :

Email : elokmath72@gmail.com

DOI : https://doi.org/10.31004/basicedu.v6i1.1990

ISSN 2580-3735 (Media Cetak)

ISSN 2580-1147 (Media Online) 


\section{PENDAHULUAN}

Matematika merupakan salah satu ilmu yang memerlukan banyak proses berpikir dan menganalisis dalam penyelesaiannya. Matematika juga banyak digunakan aplikasinya dalam kehidupan sehari-hari maupun dalam terapan-terapan ilmu lain. Sehingga, dapat dikatakan bahwa matematika berperan penting dalam perkembangan proses berpikir manusia dan juga perkembangan teknologi modern. Sebagaimana pernyataan BSNP (Subaidah, 2020) yang yang menyatakan bahwa matematika merupakan ilmu universal yang memegang peranan penting dalam proses perkembangan teknologi modern, dimana penerapannya mencakup berbagai bidang ilmu pengetahuan dan memajukan daya pikir manusia. Selain itu, matematika memiliki karakteristik yang sangat berbeda dengan ilmu pengetahuan lain seperti sifatnya yang abstrak sehingga membutuhkan kemampuan lebih untuk memahami dan mengkonstruksi materi-materi matematika. Hal ini senada dengan pendapat yang di kemukakan oleh (Ayunis \& Belia, 2021) bahwa matematika adalah salah satu mata pelajaran yang memiliki sifat khas dan selalu digunakan dalam menyelesaikan masalah di kehidupan sehari-hari.

Banyak tujuan-tujuan yang harus dicapai dalam proses pembelajaran matematika. Salah satunya adalah menumbuhkan kemampuan pemecahan masalah matematika siswa. Kemampuan pemecahan masalah matematika merupakan salah satu kemampuan yang harus dimiliki oleh setiap siswa. Terlebih, kemampuan pemecahan masalah memiliki keterkaitan dengan kehidupan sehari-hari. Banyak orang menganggap bahwa langkah-langkah dalam pemecahan masalah matematika sangat sederhana. Namun, walaupun sederhana, terkadang masih banyak siswa-siswa yang tidak memahami langkah tersebut bahkan mengabaikannya. Kemampuan pemecahan masalah matematika dapat membantu siswa untuk selalu menganalisis sebuah informasi dan menyusun berbagai alternatif penyelesaian. Hal ini sejalan dengan pendapat Julita (Subaidah, 2020) menyatakan bahwa kemampuan pemecahan masalah merupakan kemampuan memproses informasi dan menyusun berbagai alternatif pemecahan untuk mencapai tujuan yang diinginkan. Selanjutnya, menurut Suherman (Nengsih, Susiswo, \& Sa'jidah, 2019) menyatakan bahwa pemecahan masalah harus dikembangkan pada situasi yang bersifat ilmiah bertemakan kejadian dalam kehidupan sehari-hari atau yang menarik perhatian anak. Dengan kata lain, kemampuan pemecahan masalah dapat dijadikan sebagai alat untuk siswa dalam menyelesaikan berbagai masalah termasuk masalah yang berkaitan dengan kehidupan sehari-hari. Terlebih jika penyampaian atau cara menumbuhkan kemampuan pemecahan masalah pada siswa dikaitkan dengan masalah konstekstual.

Menurut (Harahap \& Surya, 2017) bahwa pemecahan masalah matematika merupakan suatu aktivitas kognitif yang kompleks, sebagai proses untuk mengatasi suatu masalah yang ditemui dan untuk menyelesaikannya diperlukan sejumlah strategi. Selanjutnya, menurut (Sumartini, 2016) bahwa pemecahan masalah merupakan suatu proses untuk mengatasi kesulitan-kesulitan yang dihadapi untuk mencapai tujuan yang diharapkan. Sedangkan menurut Polya (Rambe \& Arfi, 2020) bahwa pemecahan masalah adalah usaha mencari jalan keluar dari suatu tujuan yang tidak begitu mudah segera dapat dicapai. Berdasarkan ketiga pendapat di atas, maka dapat disimpulkan bahwa kemampuan pemecahan masalah matematika merupakan suatu kemampuan kognitif yang dapat digunakan secara penuh untuk mencari dan menemukan sebuah solusi dan tujuan yang diinginkan.

Olehnya itu, pentingnya kemampuan pemecahan masalah matematika dimiliki siswa juga diungkapkan oleh Branca (Hadi \& Radiyatul, 2014) bahwa: (1) Kemampuan menyelesaikan masalah merupakan tujuan umum pengajaran matematika, (2) Penyelesaian masalah yang meliputi metode, prosedur dan strategi merupakan proses inti dan utama dalam kurikulum matematika, dan (3) Penyelesaian masalah merupakan kemampuan dasar dalam belajar matematika. Adapun indicator kemampuan pemecahan masalah menurut NCTM (Hanifah \& Nuraeni, 2020) adalah: 1) Mengidentifikasi unsur-unsur yang diketahui, yang ditanyakan dan kecukupan unsur yang diperlukan, 2) Merumuskan masalah matematis atau menyusun model matematis, 
3) Menerapkan strategi untuk menyelesaikan berbagai masalah (sejenis dan masalah baru) dalam atau diluar matematika, dan 4) Menjelaskan atau menginterpretasikan hasil sesuai permasalahan asal. Selanjutnya, menurut Polya (Rambe \& Arfi, 2020) terdapat empat langkah yang dilakukan siswa dalam memecahkan masalah, yaitu: 1) memahami masalah, 2) merencanakan strategi pemecahan masalah, 3) melaksanakan strategi pemecahan masalah, dan 4) mengecek kembali solusi yang diperoleh. Berdasarkan kedua pendapat tersebut, maka dapat disimpulkan bahwa seorang siswa dikatakan memiliki kemampuan pemecahan masalah matematika jika memenuhi empat indikator, yakni: 1) Mampu mengidentifikasi masalah, 2) Mampu merencanakan penyelesaian masalah, 3) Mampu menyelesaikan masalah, dan 4) Mampu mengevaluasi masalah.

Namun, kenyataan yang terjadi di sekolah, masih banyak siswa yang kurang memiliki kemampuan pemecahan masalah matematika. Berdasarkan observasi awal di Madrasah Aliyah Alkhairaat Pagimana, ditemukan fenomena bahwa banyak siswa yang tidak memahami tahapan atau langkah-langkah dari pemecahan masalah khususnya pada materi Sistem Persamaan Linear Tiga Variabel (SPLTV). Berdasarkan wawancara awal dengan Guru matematika di sekolah tersebut, diperoleh informasi bahwa sebgaian besar siswa kesulitan dalam menentukan pemisalan, kesulitan dalam mengubah soal dalam bentuk verbal ke dalam bentuk matematika, dan juga siswa tidak menyimpulkan ketika menyelesaikan soal.

Kondisi ini juga didukung oleh perolehan ulangan harian pada materi SPLTV. Dari 30 siswa hanya 10 orang yang telah mencapai KKM yaitu 75. Masih terdapat 20 siswa yang nilai ulangannya tidak memenuhi KKM yang artinya masih mendapatkan nilai di bawah 75 . Hal ini, dapat diasumsikan bahwa hanya 33,3\% siswa yang memiliki kemampuan pemecahan masalah baik. Sedangkan, 66.7\% siswa lainnya masih memiliki kemampuan pemecahan masalah yang kurang. Hal ini sejalan dengan hasil penelitian yang dilakukan oleh (Utami \& Wutsqa, 2017) bahwa dari 389 siswa yang dijadikan subjek penelitian memiliki kemampuan pemecahan masalah dalam kriteria rendah. Faktor-faktor yang menyebabkan keadaan tersebut diantaranya adalah siswa kurang memahami informasi pada soal, siswa kurang mampu membuat model matematis, dan siswa kurang teliti dalam menyelesiakan soal.

Berdasarkan uraian di atas, maka sebagai alternatif adalah dengan mendeksripsikan kemampuan pemecahan masalah matematika siswa dan juga faktor-faktornya dalam menyelesaikan soal SPLTV. Dengan mendeskripsikanya, diharapkan dapat memberikan informasi yang akurat kepada guru matematika. Sehingga, informasi yang diperoleh bisa dijadikan sebagai tolak ukur untuk menentukan solusi apa yang tepat dalam menumbuhkan atau mengembangkan kemampuan pemecahan masalah matematis siswa di kelas X Madarasah Aliyah Alkhairaat Pagimana Kabupaten Banggai.

Hasil penelitian terdahulu yang dilakukan oleh (Azzahra \& Pujiastuti, 2020) dengan topik yang sama mendapatkan hasil penelitian bahwa kemampuan pemecahan masalah siswa kelas X IPS 3 SMAN 5 Kota Serang masih rendah. Hal ini karena: (1) pada tahap memahami masalah siswa belum sepenuhnya memahami masalah materi sistem persamaan linear tiga variabel; (2) pada tahap merencanakan penyelesaian siswa kesulitan dalam menuliskan strategi/rencana untuk menyelesaikan masalah; (3) pada tahap melaksanakan rencana penyelesaian siswa tidak melakukan proses perhitungan dengan benar dan tidak menemukan solusi yang tepat; dan (4) pada tahap memeriksa kembali siswa hanya sampai pada perolehan solusi tanpa memeriksa kembali dengan mensubstitusi ke persamaan awal dan juga tidak membuat kesimpulan. Hasil penelitian tersebut menunjukkan bahwa siswa masih banyak mengalami kesulitan dalam mengaplikasikan tahapan-tahapan dalam pemecahan masalah matematika. Sama halnya dengan penelitian ini, yang difokuskan adalah bagaimana mendeskripsikan secara khusus kemampuan pemecahan masalah siswa dalam menyelesaikan soal SPLTV. Temuan-temuan baru mengacu pada beberapa subjek dengan kemampuan yang berbeda-beda serta mengeksplor faktor-faktor apa saja yang mempengaruhi atau yang dapat memicu kemampuan pemecahan masalah matematika siswa. 
Harapan semua pendidik dalam dunia pendidikan khususnya pada pembelajaran matematika adalah siswa-siswa dapat menerima dan juga memahami keseluruhan materi sebagai alat untuk menyelesaikan masalah-masalah matematika maupun masalah-masalah yang berkaitan dengan kehidupan sehari-hari. Namun, pada kenyataannya masih banyak siswa yang kesulitan dalam menyelesaikan masalah-masalah matematika khususnya materi SPLTV. Sehingga, kesulitan tersebut dapat mengakibatkan rendahnya hasil belajar matematika siswa. Hal ini sesuai dengan pernyataan yang diungkapkan oleh Kuswanti, dkk (Imaroh, Umah, \& Asriningsih, 2021) bahwa kesulitan siswa dalam mempelajari matematika di sekolah menengah atas biasa dikaitkan dengan level abstraksi konsep matematika yang semakin tinggi. Sistem Persamaan Linear Tiga Variabel (SPLTV) merupakan salah satu materi jenjang pada sekolah menengah atas yang memiliki kaitan erat dengan masalah kehidupan sehari-hari. Akan tetapi, meskipun materi ini lebih mudah dihubungkan dengan masalah nyata yang sederhana, masih ada temuan kesulitan siswa dalam menyelesaikan masalah sistem persamaan linear tiga variabel. Dengan kata lain, pentingnya materi SPLTV untuk dikuasai setiap siswa, karena materi tersebut bukan hanya sekedar membahas masalah matematika tapi juga membahas masalah-masalah yang terkait dengan kehidupan sehari-hari.

Banyaknya hasil-hasil penelitian terdahulu terkait topik penelitian ini, maka berikut ini akan diuraikan beberapa hal yang meliputi temuan-temuan yang sudah ada maupun yang belum ada pada penelitianpenelitian sebelumnya. Diantaranya adalah: 1) penelitian oleh (Baskorowati, 2020) dengan judul "Studi Kasus: Analisis Kesalahan Siswa dalam Menyelesaikan Soal Cerita Matematika Materi Sistem Persamaan Linear Tiga Variabel di SMA Negeri 1 Cerme Gresik Jawa Timur". Penelitian ini membahas tentang kesalahan-kesalahan siswa dalam menyelesaikan soal cerita menggunakan kemampuan pemecahan masalah matematika. Temuan penelitian ini menggambarkan kesalahan dalam pemahaman soal, kesalahan dalam perencanaan penyelesaian, kesalahan dalam pelaksanaan rencana penyelesaian, dan kesalahan dalam pemeriksaan kembali. 2) penelitian oleh (Mairing, 2017) dengan judul "Kemampuan Siswa SMA Dalam Menyelesaikan Masalah Sistem Persamaan Linear Tiga Variabel”. Penelitian ini menunjukkan bahwa ada 3,1\% siswa yang tergolong pemecah masalah yang kurang berpengalaman, 96,9\% tergolong pemecah masalah yang rutin, dan tidak ada siswa yang tergolong pemecah masalah yang baik. Ini berarti tidak ada siswa menulis penyelesaian yang benar. Hal tersebut terjadi pada siswa-siswa yang memiliki maupun yang tidak memiliki pengetahuan prosedural mengenai cara menyelesaikan SPLTV. Hasil penelitian ini mendeskripsikan bahwa banyak siswa yang kemampuan pemecahan masalahnya tidak baik. Senada dengan penelitian ini yang juga menganalisis dan menggambarkan kemampuan pemecahan matematika siswa dalam menyelesaikan soal SPLTV. Namun, perbedaan kedua penelitian di atas dengan penelitian ini adalah dalam proses menganalisis kemampuan pemecahan masalah matematika siswa dikategorikan sesuai dengan acuan yang ada yakni "Kategori Baik" dan "Kategori Kurang". Selain itu, dalam penelitian ini juga dianalisis terkait factor yang dapat mempengaruhi kemampuan pemecahan masalah matematika siswa selama proses belajar khususnya pada materi SPLTV. Faktor-faktor yang dianalisis pun dieksplor secara umum, dimana faktor yang dimaksud bukan hanya sekedar ranah kognitif tapi ranah-ranah afektif pun dipertimbangkan.

\section{METODE PENELITIAN}

Penelitian ini dilakukan di kelas X Madrasah Aliyah Alkhairaat Pagimana Kabupaten Banggai, Provinsi Sulawesi Tengah. Penelitian ini dilakukan mulai bulan April sampai dengan Juni 2021. Jenis penelitian ini adalah deskriptif-eksploratif dengan pendekatan kualitatif. Penelitian deskriptif dilakukan dengan tujuan untuk mendeskripsikan kemampuan pemecahan masalah matematika siswa dalam menyelesaikan soal SPLTV. Sedangkan penelitian eksploratif dilakukan dengan tujuan untuk menggali informasi terkait factor-faktor yang mempengaruhinya. 
Pemilihan subjek penelitian dilakukan dengan teknik Purosive Sampling. Purposive sampling adalah teknik pengambilan sampel sumber data dengan pertimbangan tertentu, (Sugiyono, 2012). Sehingga, diperoleh 4 subjek penelitian dengan kriteria: 1) siswa berkemampuan tinggi 1 orang laki-laki dan 1 orang perempuan, dan 2) siswa berkemampuan rendah 1 orang laki-laki dan 1 orang perempuan. Instrument yang digunakan dalam penelitian adalah: 1) instrumen utama, yaitu peneliti sendiri, dan 2) instrumen pendukung, yaitu tes kemampuan pemecahan masalah matematika dan pedoman wawancara.

Teknik pengumpulan data dalam penelitian ini menggunakan observasi, tes, dokumentasi, dan wawancara. Selanjutnya, teknik analisis data menggunakan pendapat Miles and Huberman (Sugiyono, 2012) yaitu: 1) reduksi data, 2) penyajian data, dan 3) penarikan kesimpulan. Sedangkan untuk mengecek keabsahan data, dilakukan dengan menggunakan triangulasi teknik. Dimana memeriksa data dari beberapa subjek dengan menggunakan teknik yang berbeda-beda, yaitu dengan memberikan tes kemampuan pemecahan masalah dan pedoman wawancara.

\section{HASIL DAN PEMBAHASAN}

Setelah mendapatkan 4 orang siswa subjek penelitian dengan dengan menggunakan teknik Purpisive Sampling, kemudian diberikan tes kemampuan pemecahan masalah matematika materi SPLTV dengan indicator: 1) Mampu mengidentifikasi masalah, 2) Mampu merencanakan penyelesaian masalah, 3) Mampu menyelesaikan masalah, dan 4) Mampu mengevaluasi masalah. Setelah itu dilanjutkan dengan wawancara untuk menggali faktor-faktor yang mempengaruhinya. Berikut akan diuraikan hasil penelitian dan pembahasan dari keempat subjek yang sudah dipilih berdasarkan tes kemampuan pemecahan masalah matematika dengan bentuk soal sebagai berikut.

Soal 1: Pada sebuah toko Copystar Mujahid membeli 3 buah buku, 2 buah pulpen dan sebuah penghapus dengan harga Rp 7.100,00. Ramlan membeli 2 buah buku, sebuah pulpen dan sebuah penghapus dengan harga $\mathrm{Rp} 4.700,00$. Sudarco membeli sebuah buku, 2 buah pulpen dan sebuah penghapus dengan harga Rp 4.300,00. Berapakah harga untuk sebuah buku, pulpen, dan penghapus?

Soal 2: Ummi, Chyntia, dan Dhea pergi bersama-sama ke took sembako. Ummi membeli $2 \mathrm{~kg}$ beras, 2 $\mathrm{kg}$ gula, dan $1 \mathrm{~kg}$ tepung dengan harga Rp 67.000,-. Chyntia membeli $3 \mathrm{~kg}$ beras, $1 \mathrm{~kg}$ gula dan $1 \mathrm{~kg}$ tepung dengan harga $\mathrm{Rp}$ 61.000,-. Dhea membeli $1 \mathrm{~kg}$ beras, $3 \mathrm{~kg}$ gula dan $2 \mathrm{~kg}$ tepung dengan harga $\mathrm{Rp}$ 80.000,-. Tentukanlah harga $1 \mathrm{~kg}$ beras, $1 \mathrm{~kg}$ gula, dan $4 \mathrm{~kg}$ tepung!

Soal 3: Sebuah kios menjual bermacam-macam buah diantaranya Apel, Anggur, dan Jeruk. Isal membeli $1 \mathrm{~kg}$ apel, $3 \mathrm{~kg}$ anggur, dan $2 \mathrm{~kg}$ jeruk dengan harga $\mathrm{Rp} 33.000,-$. Adil membeli $2 \mathrm{~kg}$ apel, $1 \mathrm{~kg}$ anggur dan $1 \mathrm{~kg}$ jeruk dengan harga $\mathrm{Rp} 23.500$,-. Mondi membeli $1 \mathrm{~kg}$ apel, $2 \mathrm{~kg}$ anggur, dan $3 \mathrm{~kg}$ jeruk dengan harga Rp 36.500,-. Berapakah harga perkilogram apel, anggur, dan jeruk?

\section{Subjek DD (Siswa Berkemampuan Tinggi)}

Berdasarkan jawaban tes tertulis, subjek DD mampu memenuhi indicator mengidentifikasi masalah; menyusun rencana penyelesaian; dan menyelesaikan masalah berdasarkan rumus yang sudah dipilih. Namun, subjek DD tidak memenuhi indikator mengevaluasi kembali karena subjek 1 tidak memeriksa kembali jawaban dan juga tidak membuat kesimpulan akhir dari jawaban yang ada pada soal nomor 1, 2, dan 3. Hasil di atas sesuai dengan pernyataan wawancara subjek 1 yang menyatakan bahwa: " penyelesaian soal cerita, selalu dimulai dari menentukan pemisalan yang diketahui dari soal. Saya juga tau metode eliminasi dan subtitusi untuk mencari nilai yang ditanyakan. Saya juga paham mengoperasikan rumus yang saya tulis. Hanya saja saya memang tidak membuat kesimpulan dari jawaban saya".

Untuk memperkuat temuan hasil tes subjek DD, maka selanjutnya dilakukan wawancara dengan memberikan soal yang serupa dengan soal sebelumnya kepada subjek DD. Ternyata, setelah diberikan soal 
melalui wawancara, jawaban yang diberikan subjek DD sama dengan jawaban sebelumnya, yaitu tidak melakukan pemeriksaan jawaban kembali dan juga menuliskan kesimpulan. Setelah jawaban diverifikasi, dilanjutkan wawancara kembali untuk mengetahui dan mengeksplor faktor-faktor yang mempengaruhinya. Berdasarkan hasil wawancara, subjek DD menyatakan bahwa: " kalo menurut saya kak, tidak perlu memeriksa dan menyimpulkan kembali. Karena jawabannya sudah diperoleh dan sudah jelas. Saya sudah terbiasa menjawab soal SPLTV tanpa menuliskan kesimpulan kak. Kayaknya saya memang kurang teliti dalam memperhatikan jawaban jadi saya tidak memeriksa kembali jawaban dan tidak buat kesimpulan kak ". Berdasarkan uraian subjek DD, maka diperoleh sebuah penyajian data sebagai berikut.

Tabel 1. Penyajian Data Kemampuan Pemecahan Masalah Matematika Subjek DD

\begin{tabular}{|c|c|c|c|c|c|}
\hline \multirow{2}{*}{ No } & \multirow{2}{*}{$\begin{array}{c}\text { Indikator Kemampuan } \\
\text { Pemecahan Masalah Matematika }\end{array}$} & \multicolumn{3}{|c|}{ Soal } & \multirow{2}{*}{ Factor yang Mempengaruhi } \\
\hline & & 1 & 2 & 3 & \\
\hline 1. & Mampu mengidentifikasi masalah. & $\sqrt{ }$ & $\sqrt{ }$ & $\sqrt{ }$ & - Merasa tidak perlu \\
\hline 2. & $\begin{array}{l}\text { Mampu merencanakan penyelesaian } \\
\text { masalah. }\end{array}$ & $\sqrt{ }$ & $\sqrt{ }$ & $\sqrt{ }$ & $\begin{array}{l}\text { menuliskan kesimpulan } \\
\text { karena hasil akhirnya sudah }\end{array}$ \\
\hline 3. & Mampu menyelesaikan masalah. & $\sqrt{ }$ & $\sqrt{ }$ & $\sqrt{ }$ & diperoleh. \\
\hline 4. & Mampu mengevaluasi masalah. & $\mathrm{x}$ & $\mathrm{x}$ & $\mathrm{x}$ & $\begin{array}{c}\text { - Kurangnya perhatian dan } \\
\text { ketelitian dalam memeriksa } \\
\text { kembali jawaban, sehingga } \\
\text { tidak menuliskan kesimpulan } \\
\text { akhir. }\end{array}$ \\
\hline
\end{tabular}

Berdasarkan tabel 1 di atas, dapat disimpulkan bahwa subjek DD dengan kemampuan tinggi mampu memenuhi 3 dari 4 indikator kemampuan pemecahan masalah matematika. Subjek 1 sangat konsisten dalam menjawab soal SPLTV yang diberikan. Dimana subjek 1 tidak memeriksa kembali jawaban dan menyusun kesimpulan akhir. Temuan ini sesuai dengan hasil penelitian terdahulu oleh (Gunawan, 2016) dimana hasil penelitiannya menyatakan bahwa bentuk-bentuk kesalahan siswa yang terjadi pada setiap aspek yaitu: Pertama, adalah memahami soal yaitu menuliskan hal yang diketahui dan ditanyakan. Kedua, membuat model matematika. Ketiga, melakukan perhitungan. Keempat, dalam menarik kesimpulan. Selanjutnya kesalahan terbanyak yang terjadi yaitu: Pertama, aspek melakukan perhitungan. Kedua, membuat model matematika. Ketiga, memahami soal. Keempat, aspek menarik kesimpulan.

Hal tersebut disebabkan oleh kurangnya perhatian dan ketelitian dalam memeriksa kembali jawaban sehingga berakibat terbiasa tidak menuliskan kesimpulan dalam menyelesaikan soal. Kebiasaan tersebut bisa dikatakan sebuah kebiasaan yang kurang baik dalam proses pembelajaran matematika. Sehingga, subjek DD berpikir tidak perlu menuliskan kesimpulan karena jawaban akhir sudah jelas diperoleh. Hai ini sejalan dengan hasil penelitian terdahulu oleh (Nurussafa'at, Sujadi, \& Riyadi, 2016) yang menyatakan bahwa kesalahan bahasa yang dilakukan siswa tipe field dependent (FD) antara lain: (a) beranggapan bahwa menulis apa yang diketahui tidak terlalu penting karena sudah jelas apa yang ditanyakan dalam soal, (b) menurut subjek, guru tidak begitu menekankan untuk menuliskan kesimpulan dalam mengerjakan soal cerita, (c) menganggap bahwa menulis apa yang ditanyakan akan membuang waktu dan lebih ringkas apabila tidak ditulis, (d) kurang teliti dalam membaca soal sehingga mengakibatkan salah dalam menuliskan apa yang diketahui, dan (e) lupa untuk menuliskan rumus secara lengkap dan tergesa-gesa dalam mengerjakan.

\section{Subjek ET (Siswa Berkemampuan Tinggi)}

Berdasarkan hasil tes kemampuan pemecahan masalah matematika pada soal 1 dan 2 terlihat bahwa subjek ET mampu memenuhi indicator mengidentifikasi masalah; menyusun rencana penyelesaian masalah; dan menyelesaikan masalah berdasarkan rencana yang sudah disusun. Namun pada soal 3, subjek ET hanya memenhui indicator mengidentifikasi masalah dan menyusun rencana penyelesaian. Selnajutnya, subjek ET 
belum mampu memenuhi indicator menyelesaiakan masalah pada soal 3, dan mengevaluasi masalah pada soal 1, 2, dan 3. Hal ini sesuai dengan pernyataan wawancara oleh subjek ET, dimana ia menyatakan bahwa: “ untuk menjawab soal SPLTV saya membuat persamaan dengan menuliskan pemisalan. Terus saya mengambil dua persamaan dan mengeliminasinya. Setelah itu saya subtitusi nilai yang sdh didapat dari eliminasi. Kalo soal 3 ini kak, saya salah dalam menghitung. Jadi hasilnya juga salah. Terus... untuk menyimpulkan dan memeriksa kembali saya tidak lakukan kak".

Selanjutnya, subjek ET diberikan kembali soal yang setara melalui wawancara untuk mengecek keabsahan data yang diperoleh. Setelah subjek ET menyelesaikannya, ternyata apa yang ia kerjakan sama dengan jawaban sebelumnya. Setelah itu, dilanjutkan lagi wawancara untuk mengetahui faktor-faktor yang mempengaruhinya. Sehingga, diperoleh pernyataan wawancara subjek ET, yaitu: “ iya kak. Saya memang kurang perhatian ketika menyelesaikan soal matematika. Saya juga kurang ketelitian, jadi saya salah perhitungan juga kak. Kalo untuk kesimpulan, saya tidak pernah mengecek jawaban saya sudah benar atau belum. Karena saya tidak tau caranya mengecek jawaban di soal cerita kak". Berdasarkan hasil temuan dari subjek ET, maka dapat dibuat dalam penyajian data sebagai berikut.

Tabel 2. Penyajian Data Kemampuan Pemecahan Masalah Matematika Subjek ET

\begin{tabular}{|c|c|c|c|c|c|}
\hline \multirow{2}{*}{ No } & \multirow{2}{*}{$\begin{array}{c}\text { Indikator Kemampuan } \\
\text { Pemecahan Masalah Matematika }\end{array}$} & \multicolumn{3}{|c|}{ Soal } & \multirow{2}{*}{ Factor yang Mempengaruhi } \\
\hline & & 1 & 2 & 3 & \\
\hline 1. & Mampu mengidentifikasi masalah. & $\sqrt{ }$ & $\sqrt{ }$ & $\sqrt{ }$ & Kurangnya perhatian dalam \\
\hline 2. & $\begin{array}{l}\text { Mampu merencanakan penyelesaian } \\
\text { masalah. }\end{array}$ & $\sqrt{ }$ & $\sqrt{ }$ & $\sqrt{ }$ & $\begin{array}{l}\text { menyelesaikan soal. } \\
\text { - Kurangnya ketelitian dalam }\end{array}$ \\
\hline 3. & Mampu menyelesaikan masalah. & $\sqrt{ }$ & $\sqrt{ }$ & $\mathrm{x}$ & perhitungan. \\
\hline 4. & Mampu mengevaluasi masalah. & $\mathrm{x}$ & $\mathrm{x}$ & $\mathrm{x}$ & $\begin{array}{l}\text { - Tidak mengetahui cara untuk } \\
\text { mengecek jawaban dari soal } \\
\text { bentuk cerita. }\end{array}$ \\
\hline
\end{tabular}

Berdasarkan tabel 2 di atas, dapat disimpulkan bahwa secara keseluruhan indicator kemampuan pemecahan masalah yang dipenuhi oleh subjek ET adalah mengidentifikasi masalah dan menyusun perencanaan penyelesaian masalah. Sedangkan indicator menyelesaikan masalah dan mengevaluasi masalah belum dipenuhi oleh subjek ET. Temuan ini sejalan dengan hasil penelitian yang dilakukan oleh (Fauziyah \& Pujiastuti, 2020) dimana hasil penelitiannya menunjukkan bahwa persentase kesalahan siswa kelas XI IPS SMA Negeri 5 Kota Serang dalam menyelesaikan soal cerita Program Linear berdasarkan prosedur Polya yaitu kesalahan memahami masalah soal cerita Program Linear sebesar 11,35\% dengan kategori sangat rendah. Kesalahan membuat perencanaan sebesar 21,28\% dengan kategori rendah. Kesalahan melaksanakan perencanaan sebesar 29,79\% dengan kategori rendah. Kesalahan mengecek kembali sebesar 37,59\% dengan kategori rendah. Kesalahan paling banyak dilakukan siswa terletak pada kesalahan mengecek kembali sebesar $37,59 \%$.

Hal ini disebabkan oleh kurangnya ketelitian, perhatian, dan juga kurangnya lemahnya konsep pembuktian atau tidak mengetahui cara mengecek sebuah jawaban. Masalah yang dialami oleh subjek ET ini sejalan dengan hasil penelitian sebelumnya yang dilakukan oleh (Zulfitri, Aisyah, \& Indaryanti, 2019) yakni indikator kemampuan pemecahan masalah yang sering muncul ialah indikator memahami masalah, dimana indikator ini muncul disetiap tingkat kemampuan siswa yaitu tinggi, sedang, dan rendah. Sedangkan indikator yang sangat jarang muncul ialah indikator melihat kembali. Penyebab indikator ini jarang muncul karena kebanyakan siswa tidak menghiraukan perintah soal untuk melihat kembali, siswa merasa cukup dengan perolehan hasil akhir tanpa menganalisis kembali hasil yang telah diperoleh. 


\section{Subjek SL (Siswa Berkemampuan Rendah)}

Setelah menelisik jawaban tes subjek SL diperoleh bahwa subjek SL mampu dalam merencanakan penyelesaian masalah pada soal 1, 2, dan 3. Namun subjek SL belum mampu mengidentifikasi masalah, menyelesaikan masalah, dan mengevaluasi masalah pada soal 1, 2, dan 3. Hal ini sesuai dengan pernyataan wawancara subjek SL yang menyatakan: " saya tidak bisa memisalkan dari soal cerita kak. Kalo persamaannya saya bisa buat. Mmm... kalo untuk menyelesaikan soal cerita saya tau selalu menggunakan eliminasi subtitusi. Hanya saja saya masih sulit menerapkannya kak. Saya juga tidak tau caranya memeriksa jawaban. Terus membuat kesimpulan juga saya tidak tau".

Untuk meyakinkan jawaban subjek SL, maka dilakukan wawancara dengan memberikan soal yang setara dengan soal sebelumnya. Hasilnya pun sama dengan sebelumnya. Sehingga, wawancara dilanjutkan untuk mengetahui factor-faktor yang mempengaruhinya. Dari hasil wawancara yang dilakukan diperoleh pernyataan subjek SL, bahwa: “ saya kurang memperhatikan ketika guru menjelaskan kak. Karena saya tidak suka pelajaran matematika. Saya juga tidak aktif di kelas kak. Saya tidak bisa mengoperasikan matematika apalagi ada tanda negatif dan positif. Karena saya tidak bisa menyelesaikan soal cerita saya juga tidak bisa menyimpulkan kak". Berdasarkan hasil tes dan wawancara subjek SL, maka dapat disajikan dalam penyajian data berikut.

Tabel 3. Penyajian Data Kemampuan Pemecahan Masalah Matematika Subjek SL

\begin{tabular}{|c|c|c|c|c|c|}
\hline \multirow{2}{*}{ No } & \multirow{2}{*}{$\begin{array}{c}\text { Indikator Kemampuan Pemecahan } \\
\text { Masalah Matematika }\end{array}$} & \multicolumn{3}{|c|}{ Soal } & \multirow{2}{*}{ Factor yang Mempengaruhi } \\
\hline & & 1 & 2 & 3 & \\
\hline 1. & Mampu mengidentifikasi masalah. & $\mathrm{x}$ & $\sqrt{ }$ & $\mathrm{x}$ & - Kurangnya perhatian dalam \\
\hline 2. & $\begin{array}{l}\text { Mampu merencanakan penyelesaian } \\
\text { masalah. }\end{array}$ & $\mathrm{x}$ & $\sqrt{ }$ & $\mathrm{x}$ & $\begin{array}{c}\text { proses pembelajaran. } \\
\text { - } \quad \text { Tidak menyukai pelajaran }\end{array}$ \\
\hline 3. & Mampu menyelesaikan masalah. & $\mathrm{x}$ & $\sqrt{ }$ & $\mathrm{X}$ & matematika. \\
\hline 4. & Mampu mengevaluasi masalah. & $\mathrm{x}$ & $\mathrm{x}$ & $\mathrm{x}$ & 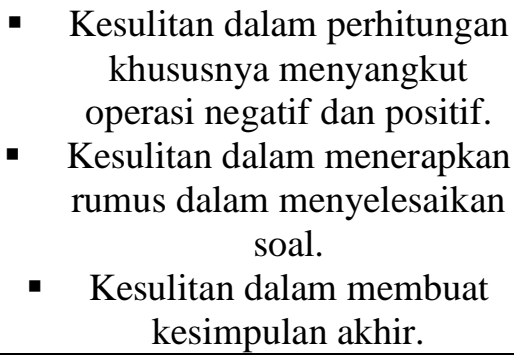 \\
\hline
\end{tabular}

Berdasarkan tabel 3 di atas dapat disimpulkan bahwa subjek SL hanya memenuhi indicator kemampuan pemecahan masalah matematika pada aspek merencanakan penyelesaian masalah. Sedangkan indicator yang tidak dipenuhi oleh subjek SL adalah mengidentifikasi masalah, menyelesaikan masalah, dan mengevaluasi masalah. Hal ini disebabkan oleh kurangnya perhatian selama proses pembelajaran berlangsung, tidak menyukai matematika, kesulitan dalam perhitungan, kesulitan dalam menerapkan rumus, dan kesulitan dalam menyimpulkan. Hal ini sejalan dengan hasil penelitian sebelumnya oleh (Kudsiyah, Novarina, \& Lukman, 2017) yang menyatakan bahwa terdapat lima belas faktor yang mempengaruhi kemampuan pemecahan masalah matematikan, yaitu: kesulitan belajar, penguasaan materi, konteks soal, pemahaman, berfikir panjang, belajar sebelumnya, rumus, sikap (suka/tidak suka), mood, motivasi, perhatian, rasa malas, respon/tanggapan, keaktifan, dan diskusi. Namun hanya delapan faktor yang memiliki pengaruh yang signifikan, diantaranya: Kesulitan belajar memiliki pengaruh $25 \%$, sikap (suka/tidak suka) memiliki pengaruh $14.44 \%$, perhatian memiliki pengaruh $9.61 \%$, rasa malas memiliki pengaruh $9 \%$, rumus memiliki pengaruh $7.84 \%$, respon memiliki pengaruh $7.29 \%$, belajar sebelumnya memiliki pengaruh $6.76 \%$, dan motivasi memiliki pengaruh $5.76 \%$. 


\section{Subjek DA (Siswa Berkemampuan Rendah)}

Setelah mencermati jawaban subjek DA terlihat bahwa subjek DA belum mampu memenuhi indikator kemampuan pemecahan masalah matematika, yaitu mengidentifikasi masalah, menyusun perencanaan pemecahan masalah, menyelesaikan masalah, dan mengevaluasi masalah. Hal ini sesuai dengan pernyataan subek DA, bahwa: “ saya terbiasa tidak menuliskan apa yang diketahui dan ditanya, karena saya masih bingung dalam memisalkan. Saya tidak tau apa yang harus dimisalkan dari soal. Tapi kalo menyelesaikan soal cerita saya tau rumus yang digunakan adalah rumus eliminasi. Saya tidak tau rumus yang lainnya. Tapi saya tidak tau caranya mengeliminasi. Apalagi untuk mengecek jawaban dan menyimpulkan. Saya tidak tau kak".

Untuk melihat kekonsistenan jawaban subjek DA, maka subjek DA kembali diberikan soal yang setara dengan sebelumnya. Setelah melihat jawaban subjek DA pada saat wawancara, ternyata jawabannya sama dengan sebelumnya. Sehingga, wawancara dilanjutkan untuk mengeksplor faktor-faktor yang mempengaruhinya. Melalui wawancara ini dipeoroleh pernyataan subjek DA, bahwa: “ saya kurang memperhatikan guru menjelaskan kak. Saya juga lemah dengan dasar-dasar matematika. Jadi, saya sulit mengerjakan soal-soal matematika. Apalagi soal cerita kak. Saya juga kesulitan dalam operasi hitung yang digabungkan dengan variabel-variabel. Saya juga tidak bisa menggunakan rumus untuk menyelesaikan soal. Pokoknya saya lemah dalam pelajaran matematika kak. Kalo menyelesaikan soal cerita saya tidak pernah tuntas". Berdasarkan temuan dari subjek DA, maka dapat dibuat penyajian data sebagai berikut.

Tabel 4. Penyajian Data Kemampuan Pemecahan Masalah Matematika Subjek DA

\begin{tabular}{|c|c|c|c|c|c|}
\hline \multirow{2}{*}{ No } & \multirow{2}{*}{$\begin{array}{c}\text { Indikator Kemampuan Pemecahan } \\
\text { Masalah Matematika }\end{array}$} & \multicolumn{3}{|c|}{ Soal } & \multirow{2}{*}{ Factor yang Mempengaruhi } \\
\hline & & 1 & 2 & 3 & \\
\hline 1. & Mampu mengidentifikasi masalah. & $\mathrm{x}$ & $\mathrm{x}$ & $\mathrm{x}$ & - Kurangnya perhatian dalam \\
\hline 2. & $\begin{array}{l}\text { Mampu merencanakan penyelesaian } \\
\text { masalah. }\end{array}$ & $\mathrm{x}$ & $\mathrm{x}$ & $\mathrm{x}$ & $\begin{array}{l}\text { proses pembelajaran. } \\
\text { - Lemahnya konsep dasar }\end{array}$ \\
\hline 3. & Mampu menyelesaikan masalah. & $\mathrm{x}$ & $\mathrm{x}$ & $\mathrm{x}$ & matematika. \\
\hline 4. & Mampu mengevaluasi masalah. & $\mathrm{x}$ & $\mathrm{x}$ & $\mathrm{x}$ & $\begin{array}{l}\text { - } \begin{array}{c}\text { Kesulitan dalam perhitungan } \\
\text { bentuk aljabar. }\end{array} \\
\text { - } \quad \text { Kesulitan dalam menerapkan } \\
\text { rumus dalam menyelesaikan } \\
\text { soal. } \\
\text { - Kesulitan dalam } \\
\text { menyelesaikan soal cerita. }\end{array}$ \\
\hline
\end{tabular}

Berdasarkan tabel 4 di atas, dapat disimpulkan bahwa subjek DA belum mampu dalam menerapkan langkah-langkah kemampuan pemecahan masalah matematika dalam menyeleslaikan soal matematika khususnya pada materi SPLTV. Hal ini disebabkan oleh kurangnya perhatian ketika guru menjelaskan, lemahnya konsep dasar matematika, kesulitan dalam mengoperasikan bentuk aljabar, kesulitan menerapkan rumus, dan kesulitan menyelesaikan soal cerita. Hal ini sesuai dengan pendapat (Noviyanti, Purnomo, \& Kusumaningsih, 2021) yang menyatakan bahwa kesulitan siswa terutama dalam pemecahan masalah menurut pandangan guru disebabkan karena sulitnya siswa memahami masalah, membuat rencana dalam penyelesaikan masalah tersebut, menjabarkan serta mengaitkan dengan pengetahuan sebelumnya. Selain itu siswa juga kesulitan memahami kalimat yang tertera dalam persoalan, kurang familiar dengan permasalahan yang disuguhkan serta kurang dapat menerapkan strategi untuk menyelesaikan permasalahan. 


\section{KESIMPULAN}

Subjek DD dan ET dengan kemampuan tinggi memiliki kemampuan pemecahan masalah yang sama. Dimana kedua subjek tersebut sama-sama belum mampu memenuhi indicator mengevaluasi masalah. Faktor yang mempengaruhinya adalah kurangnya perhatian, ketelitian, dan tidak mengetahui cara dalam mengecek kebenaran suatu jawaban. Subjek SL dan DA dengan kemampuan rendah memiliki kemampuan pemecahan masalah matematika yang sedikit berbeda. Subjek SL belum mampu memenuhi indikator mengidentifikasi masalah, menyelesaikan masalah, dan mengevaluasi masalah. Sedangkan subjek DA, belum mampu memenuhi indikator mengidentifikasi masalah, merencanakan penyelesaian, menyelesaiakan masalah, dan mengevaluasi masalah. Faktor yang mempengaruhinya adalah, kurangnya perhatian dalam proses pembelajaran, tidak menyukai pelajaran matematika, kesulitan dalam perhitungan khususnya menyangkut operasi negatif dan positif, kesulitan dalam menerapkan rumus dalam menyelesaikan soal, kesulitan dalam membuat kesimpulan akhir, lemahnya konsep dasar matematika, kesulitan dalam perhitungan bentuk aljabar, dan kesulitan dalam menyelesaikan soal cerita.

\section{DAFTAR PUSTAKA}

Ayunis, \& Belia, S. (2021). Pengaruh Pendekatan Realistic Mathematics Education (Rme) Terhadap Perkembangan Literasi Matematika Siswa Di Sekolah Dasar. Jurnal Basicedu: Research \& Learning Elementary Education, 5(6), 5363-5369. Https://Doi.Org/Https://Doi.Org/10.31004/Basicedu.V5i6.1508

Azzahra, R. H., \& Pujiastuti, H. (2020). Analisis Kemampuan Pemecahan Masalah Siswa Pada Materi Sistem Persamaan Linear Tiga Variabel. Transformasi: Jurnal Pendidikan Matematika Dan Matematika, 4(1), 153-162. Https://Doi.Org/Https://Doi.Org/10.36526/Tr.V4i1.876

Baskorowati, H. (2020). Studi Kasus: Analisis Kesalahan Siswa Dalam Menyelesaikan Soal Cerita Matematika Materi Sistem Persamaan Linear Tiga Variabel Di Sma Negeri 1 Cerme Gresik Jawa Timur. Jurnal Mathedunesa, 9(3), 529-539. Https://Doi.Org/Https://Doi.Org/10.26740/Mathedunesa.V9n3.P529-539

Fauziyah, R. S., \& Pujiastuti, H. (2020). Analisis Kesalahan Siswa Dalam Menyelesaikan Soal Cerita Program Linear Berdasarkan Prosedur Polya. Union: Jurnal Pendidikan Matematika, 8(2), 253-264. Retrieved From Https://Jurnal.Ustjogja.Ac.Id/Index.Php/Union/Article/View/7747/Pdf

Gunawan, A. (2016). Analisis Kesalahan Dalam Menyelesaikan Soal Cerita Pada Mata Pelajaran Matematika Siswa Kelas V Sdn 59 Kota Bengkulu. Jurnal Pgsd: Jurnal Ilmiah Pendidikan Guru Sekolah Dasar, 9(2), 216-225. Retrieved From Https://Ejournal.Unib.Ac.Id/Index.Php/Pgsd/Article/Viewfile/4618/2511

Hadi, S., \& Radiyatul. (2014). Metode Pemecahan Masalah Menurut Polya Untuk Mengembangkan Kemampuan Siswa Dalam Pemecahan Masalah Matematis Di Sekolah Menengah Pertama. Edu-Mat Jurnal Pendidikan Matematika, 2(1), 53-61. Https://Doi.Org/Http://Dx.Doi.Org/10.20527/Edumat.V2i1.603

Hanifah, H. R. F. N., \& Nuraeni, R. (2020). Perbedaan Peningkatan Kemampuan Pemecahan Masalah Matematis Siswa Antara Think Pair Share Dan Think Talk Write. Mosharafa: Jurnal Pendidikan Matematika Stkip Garut, 9(1), 155-166.

Harahap, E. R., \& Surya, E. (2017). Kemampuan Pemecahan Masalah Matematis Siswa Kelas Vii Dalam Menyelesaikan Persamaan Linear Satu Variabel. In Seminar Nasional Matematika: Peran Alumni Matematika Dalam Membangun Jejaring Kerja Dan Peningkatan Kualitas Pendidikan (Pp. 286-279). Medan: Semnastika Unimed.

Imaroh, A., Umah, U., \& Asriningsih, T. M. (2021). Analisis Kemampuan Pemecahan Masalah Matematika Ditinjau Dari Self-Efficacy Siswa Pada Materi Sistem Persamaan Linear Tiga Variabel. Jpmi: Jurnal Pembelajaran Matematika Inovatif, 4(4), 843-856. Https://Doi.Org/10.22460/Jpmi.V4i4.843-856 
Kudsiyah, S. M., Novarina, E., \& Lukman, H. S. (2017). Faktor-Faktor Yang Mempengaruhi Kemampuan Pemecahan Masalah Mmatematika Kelas X Di Sma Negeri 2 Kota Sukabumi. In Seminar Nasional Pendidikan (Pp. 110-117). Sukabumi. Retrieved From Http://Eprints.Ummi.Ac.Id/202/

Mairing, J. P. (2017). Kemampuan Siswa Sma Dalam Menyelesaikan Masalah Sistem Persamaan Linear Tiga Variabel. Aksioma, 6(1), 15-26. Https://Doi.Org/Https://Doi.Org/10.22487/Aksioma.V6i1.137

Nengsih, L. W., Susiswo, \& Sa'jidah, C. (2019). Kemampuan Pemecahan Masalah Matematika Siswa Sekolah Dasar Dengan Gaya Kognitif Field Dependent. Jurnal Pendidikan: Teori, Penelitian, Dan Pengembangan, 4(2), 143-148. Https://Doi.Org/Http://Dx.Doi.Org/10.17977/Jptpp.V4i2.11927

Noviyanti, E. D., Purnomo, D., \& Kusumaningsih, W. (2021). Analisis Kemampuan Berpikir Reflektif Dalam Pemecahan Masalah Matematika Ditinjau Dari Gaya Kognitif. Imajiner: Jurnal Matematika Dan Pendidikan Matematika, 3(1), 57-68.

Nurussafa'at, F. A., Sujadi, I., \& Riyadi. (2016). Analisis Kesalahan Siswa Dalam Menyelesaikan Soal Cerita Pada Materi Volume Prisma Dengan Fong's Shcematic Model For Error Analysis Ditinjau Dari Gaya Kognitif Siswa. Jurnal Elektronik Pembelajaran Matematika, 4(2), 174-187.

Rambe, A. Y. F., \& Arfi, L. D. (2020). Analisis Kemampuan Pemecahan Masalah Matematis Siswa Dalam Menyelesaikan Soal Materi Barisan Dan Deret. Axiom: Jurnal Pendidikan Dan Matematika, 9(2), 175187. Https://Doi.Org/Http://Dx.Doi.Org/10.30821/Axiom.V9i2.8069

Subaidah. (2020). Kemampuan Memecahkan Masalah Matematika Kelas X Ips Sma Wijaya Putra Surabaya Pada Materi Sistem Persamaan Linear Tiga Variabel Dengan Teori Polya. Ed-Humanistics : Jurnal Ilmu Pendidikan, 5(1), 674-680. Https://Doi.Org/10.33752/Ed-Humanistics.V5i1.710

Sugiyono. (2012). Metode Penelitian Pendidikan )Pendekatan Kuantitatif, Kualitatif, Dan R\&D) (Cetakan $\mathrm{Ke})$. Bandung: Alfabeta.

Sumartini, T. S. (2016). Peningkatan Kemampuan Pemecahan Masalah Matematis Siswa Melalui Pembelajaran Berbasis Masalah. Mosharafa: Jurnal Pendidikan Matematika Stkip Garut, 5(2), 148-158.

Utami, R. W., \& Wutsqa, D. U. (2017). Analisis Kemampuan Pemecahan Masalah Matematika Dan SelfEfficacy Siswa Smp Negeri Di Kabupaten Ciamis. Jurnal Riset Pendidikan Matematika, 4(2), 166-175. Https://Doi.Org/Http://Dx.Doi.Org/10.21831/Jrpm.V4i2.14897

Zulfitri, H., Aisyah, N., \& Indaryanti. (2019). Analisis Kemampuan Pemecahan Masalah Matematika Setelah Pembelajaran Dengan Pendekatan Meas Pada Materi Sistem Persamaan Linier Tiga Variabel. Jurnal Gantang, 4(1), 7-13. Https://Doi.Org/Https://Doi.Org/10.31629/Jg.V4i1.881 